\title{
Crystallinity, thermal and pasting properties of starches from different potato cultivars grown in Brazil
}

\author{
Thais Paes R. dos Santos, Magali Leonel*, Émerson L. Garcia, Ezequiel L. do Carmo, \\ Célia Maria L. Franco
}

UNESP, CERAT, Rua José Barbosa de Barros, 1780 Botucatu, Brazil

\section{A R T I C L E I N F O}

\section{Article history:}

Received 11 May 2015

Received in revised form 28 October 2015

Accepted 30 October 2015

Available online 10 November 2015

\section{Keywords:}

Amylose

Phosphorus

Gelatinization

Retrogradation

Pasting temperature

\begin{abstract}
A B S T R A C T
Starches from different potato cultivars were characterized as amylose and phosphorus content, crystallinity, thermal and paste properties. Statistical analysis of amylose content showed difference between starches samples and the cultivars Asterix and BRS Clara showed higher contents than others. Phosphorus content ranged from 633 to $966.7 \mathrm{mg} \mathrm{kg}^{-1}$. The X-ray diffraction analysis showed that the crystallization of potato starches can be classified as B-type X-ray pattern, presenting crystallinity index ranging from $20.02 \%$ to $21.59 \%$. Regarding thermal properties, the onset temperature did not show statistical difference between starch samples, in gelatinization and retrogradation analysis. As expected there was a significant decrease in peak temperature and enthalpy after the retrogradation of starches. For the pasting properties results showed significant difference in all cultivars. Pearson correlation coefficients showed that amylose content was negatively correlated to the onset, peak and final temperature of gelatinization, final temperature of retrogradation and pasting temperature. Phosphorus content was positively correlated to crystallinity index, peak viscosity and breakdown. Starches extracted from potato varieties showed different characteristics which can be useful to food and related industries that make use of potato starch, allowing wide options of use in various sectors of industrial application in Brazil.
\end{abstract}

Published by Elsevier B.V.

\section{Introduction}

Potato (Solanum tuberosum) is one of the most important crops in the feeding the world population. It is in fourth in world production, after rice, wheat and maize, presenting nearly 36.7 million tons harvested in 2013. In the same year was harvest in Brazil 3.57 million tons of potatoes [1]. However, it is estimated that less than $50 \%$ of potatoes grown worldwide are consumed fresh. Industrial uses of potatoes include products like frozen fries, flakes, snacks, flour and starch [2].

Potatoes are planted in almost all Brazilian states although commercial cultivation is practiced predominantly in the South and Southeast where soil and climatic conditions are more favorable and the cultivation is strongest. More recently, the commercial cultivation has advanced to the states of Goiás and Bahia, Midwest and Northeast regions of Brazil respectively, which have plateaus with soil and climate conditions highly favorable to culture [3].

\footnotetext{
* Corresponding author.

E-mail addresses: mleonel@cerat.unesp.br, secretaria@cerat.unesp.br (M. Leonel).
}

The potato stands out as tuber culture of greater economic importance to Brazil, being the country self-sufficient in the production of the same, though the consumption being only of the tuber in nature. Due to it, the country depends on the import of potato starch, because although there are great areas of cultivation, there is no processing of these tubers for extraction and marketing of starch. Starch is composed exclusively of glucose residues linked by only two types of bonds: $\alpha-1,4$ and $\alpha-1,6$ glycoside linkages. Amylose and amylopectin make up $98-99 \%$ of the dry weight of native granules, with the remainder comprising small amounts of lipids, minerals, and phosphorus in the form of phosphate esters. Amylopectin in the granule is present in the semi-crystalline structure, while amylose is located in amorphous. Starch granules possess different X-ray patterns, displaying A, B and C-type, depending on their amylopectin branch chain-length [4,5].

Starch varies greatly in form and functionality between and within botanical species, and even from the same plant cultivar grown under different conditions. This variability provides starches of diverse properties [6]. Starch contributes greatly to the textural properties of many foods and has many industrial applications as a thickener, colloidal stabilizer, gelling agent, bulking agent, water retention agent and adhesive [6]. 
Most starch consumed by humans has undergone some form of processing, which usually involves heating in the presence of moisture under shear, and then cooling. During heat treatment, the starch granules are gelatinized, losing their crystallinity and structural organization. On cooling, the disaggregated starch molecules firstly form a gel and then retrograde gradually into semi crystalline aggregates that differ in form from the native granules. Understanding the steps that occur during gelatinization and retrogradation of a particular starch are key steps to better predict the functional properties of processed starch from knowledge of the structure of native granules [5].

The different pasting properties of starch from different cultivars may be due to the difference in granular size, phosphorous content and amylose content of starch granules. Considering pasting properties potato starches has the highest pasting viscosity, this characteristics is largely attributed to starch-bound phosphate [7]. The presence of phosphate groups in starch increases the hydration capacity of starch pastes after gelatinization, resulting in a correlation between the starch phosphate content and the starch viscosity changes and the gel-forming capacity [8]. Potato starches has higher concentration of phosphate than the starches from others botanical sources [9].

The relationship between the structural characteristics and functional properties of starches has received much attention, since it is important to understanding how the functional properties of starch are affected by its structural features. This information could provide the basis for further manipulation of appropriate quality attributes [10] and understand starch behavior and utilization [7]. The cooking, textural and rheological properties of potatoes are related to the physicochemical, morphological, thermal and rheological properties of their starches [11].

Considering the importance of the potato as a world source of starch, the fact that Brazil is the second largest producer of cassava starch with large companies involved with this process, and the yield potential of potato starch in the country, this study aimed to determine the crystallinity, thermal and pasting properties of starches which were isolated from six potato cultivars grown in Brazil in order to obtain information about their properties targeting future applications.

\section{Material and methods}

\subsection{Raw materials used}

The potato cultivars were grown in the Pouso Alegre city, Minas Gerais state, Brazil. The cultivars used were: Asterix, Atlantic, BRS Clara, Ágata, Mustang and Fontane. The extractions were performed by physical method with three repetitions by cultivar [12]. The moisture, lipids and protein content of the starches were determined following the AOAC [13].

\subsection{Amylose content}

Amylose content was determined according to ISO-6674 method [14]. The amylose content was calculated from standard curves of amylose and the results were expressed as percentage of amylose.

\subsection{Phosphorus content}

Phosphorus content was determined according to Malavolta et al. [15]. The phosphorus content in the digestion was measured as inorganic phosphorus, using the vanado-molybdate method to calculate the phosphorus content of starch (absorbance read at $420 \mathrm{~nm})$

\subsection{X-ray analysis}

Crystallinity were determined as follows, the starches were kept in a desiccator containing saturated solution of $\mathrm{BaCl}_{2}\left(25^{\circ} \mathrm{C}\right.$, $\mathrm{aw}=0.9$ ) for 10 days for moisture balance. The X-ray diffraction patterns of the starches were then determined using a Wide Angle Goniometer unit (RINT2000, Rigaku, Tokyo, Japan), with $\mathrm{Cu} \mathrm{K \alpha}$ radiation $(\lambda=0.1542 \mathrm{~nm})$. The scanning speed was $1^{\circ} / \mathrm{min}$ at $50 \mathrm{kV}$ and $100 \mathrm{~mA}$. The relative crystallinity was quantitatively estimated based on the relationship between the peak and total areas following the method of Nara and Komiya [16] using the Origin software (version 7.5, Microcal Inc., Northampton, MA, USA).

\subsection{Thermal properties (DSC)}

The thermal properties of potato starches were analyzed using a differential scanning calorimeter (DSC) Pyris 1 (Perkin Elmer, USA). Starch samples (about $2.5 \mathrm{mg}$, dry basis) were weighed into aluminum pans, mixed with distilled water $(7.5 \mu \mathrm{L})$ and sealed. The sealed pans were kept at room temperature for $2 \mathrm{~h}$ for balance and heated at a rate of $10^{\circ} \mathrm{C} \mathrm{min}^{-1}$ from $25^{\circ} \mathrm{C}$ to $100^{\circ} \mathrm{C}$. An empty pan was used as reference. After running the samples in DSC, they were refrigerated at $4{ }^{\circ} \mathrm{C}$ for 14 days and analyzed again under the same conditions to determine the thermal properties of retrograded starches. Gelatinization temperature (onset, peak and final) and enthalpy change of native and retrograded starches were determined using the Pyris 1 software from Perkin Elmer, USA [17].

\subsection{Pasting properties}

Pasting properties of potato starches were determined using a Rapid Visco Analyzer (Model RVA 4, Newport Scientific Pty. Ltd., Warriewood, Australia), using starch suspensions (2.5 g of starch in $25 \mathrm{~mL}$ of water), corrected for the basis of $14 \%$ of moisture. The program used was Standard 1 and viscosity was expressed as RVU. Obtaining results for peak viscosity, breakdown, final viscosity, retrogradation and pasting temperature.

\subsection{Statistical analysis}

Analysis of variance (ANOVA) and Tukey's test were used to conduct the statistical analysis of results. Significant differences were reported for $p<0.05$. Pearson correlation coefficients were determined to evaluate relationship between variables.

\section{Results and discussion}

Table 1 shows the chemical composition of potato starches. Protein content ranged from 0.19 to $0.31 \%$. Lipids content of potato starches showed low values ranging from $0.04 \%$ (Atlantic) to $0.14 \%$ (Mustang). The amylose content of potato starches presented low variation. Asterix cultivar had the highest amylose content $(23.43 \%)$ while Mustang cultivar had the lowest value (16.10\%). Amylose and amylopectin contents affect starch granule architecture in pasting properties, textural attributes and application for processed food. Similar results were found by Buléon et al. [18] and Noda et al. [19]. Results from Asterix cultivar confirmed previous reported results in which the phosphorus content was negatively correlated with the amylose content in potato starch [7,20]. Phosphorus content of potato starches ranged from $633 \mathrm{mg} \mathrm{kg}^{-1}$ (Asterix) to $966.7 \mathrm{mg} \mathrm{kg}^{-1}$ (Atlantic). The range of the phosphorus content was similar to that reported by Noda et al. [7], Noda et al. [19], Veselovsky [21], Wiesenborn et al. [22] and Kim et al. [23].

X-ray patterns of potato starches from different potato cultivars are presented in Fig. 1. All samples showed a typical B-type $\mathrm{X}$-ray pattern, with major peaks at 5.6, 15, 17, 18 and 23 in $2 \theta$. 
Table 1

Protein, lipids, amylose and phosphorus content of potato starches.

\begin{tabular}{|c|c|c|c|c|}
\hline Samples & Protein (\%) & Lipids (\%) & Amylose (\%) & Phosphorus ( $\mathrm{mg} \mathrm{kg}^{-1}$ ) \\
\hline Asterix & $0.31 \pm 0.01^{\mathrm{b}}$ & $0.09 \pm 0.01^{b}$ & $23.47 \pm 1.17^{c}$ & $633 \pm 57.7^{a}$ \\
\hline Atlantic & $0.25 \pm 0.04^{\mathrm{ab}}$ & $0.04 \pm 0.01^{\mathrm{a}}$ & $20.33 \pm 0.63^{\mathrm{abc}}$ & $966.7 \pm 132.4^{\mathrm{d}}$ \\
\hline BRS Clara & $0.26 \pm 0.05^{\mathrm{ab}}$ & $0.11 \pm 0.01^{\mathrm{bc}}$ & $23.33 \pm 3.33^{c}$ & $933 \pm 100.0^{c}$ \\
\hline Ágata & $0.20 \pm 0.01^{\mathrm{ab}}$ & $0.10 \pm 0.02^{\mathrm{bc}}$ & $17.50 \pm 1.11^{\mathrm{ab}}$ & $733 \pm 152^{\mathrm{b}}$ \\
\hline Mustang & $0.28 \pm 0.04^{\mathrm{ab}}$ & $0.14 \pm 0.01^{\mathrm{c}}$ & $16.10 \pm 0.21^{\mathrm{a}}$ & $700 \pm 100.0^{\mathrm{b}}$ \\
\hline Fontane & $0.19 \pm 0.02^{\mathrm{a}}$ & $0.07 \pm 0.01^{\mathrm{ab}}$ & $20.97 \pm 0.79^{b c}$ & $900 \pm 100.0^{c}$ \\
\hline
\end{tabular}

Means in the same column with different letters are significantly different $(p<0.05)$.

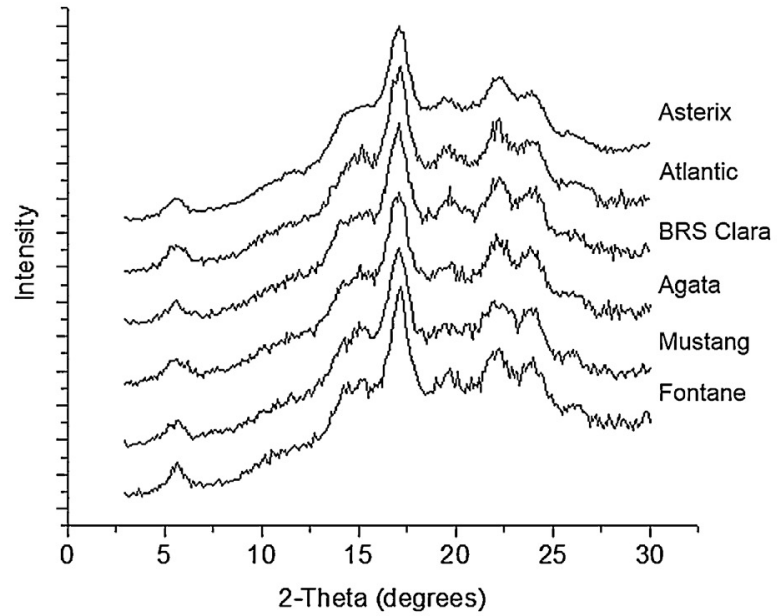

Crystallinity index (\%)

$\begin{array}{cccccc}\text { Asterix } & \text { Atlantic } & \text { BRS Clara } & \text { Ágata } & \text { Mustang } & \text { Fontane } \\ 20.00 \pm 0.17^{\mathrm{a}} & 21.00 \pm 0.23^{\mathrm{ab}} & 20.50 \pm 0.09^{\mathrm{ab}} & 21.00 \pm 0.13^{\mathrm{ab}} & 20.50 \pm 0.46^{\mathrm{ab}} & 22.00 \pm 0.09^{\mathrm{b}}\end{array}$

Fig. 1. X-ray diffraction patterns and crystallinity index of investigated potato starches. Means in the same line with different letters are significantly different $(p<0.05$ ).

These results agree with those related by Zobel [24,25], Jane et al. [26], Buléon et al. [18], Protserov et al. [27]. The polymerization degree of the branched chains of amylopectin is related to the type of polymorphism [28] and in B-type starches typically exhibit large portion of long-chain ( $\mathrm{DP}>37$ ). The crystallinity index of the potato starches ranged from $20.02 \%$ to $21.59 \%$.

Data of thermal properties of potato starches are summarized in Table 2, and DSC gelatinization curves are shown in Fig. 2. The peak and final temperature and gelatinization enthalpies showed significant difference between potato starches samples, whereas no significant difference was found in onset temperature. The results

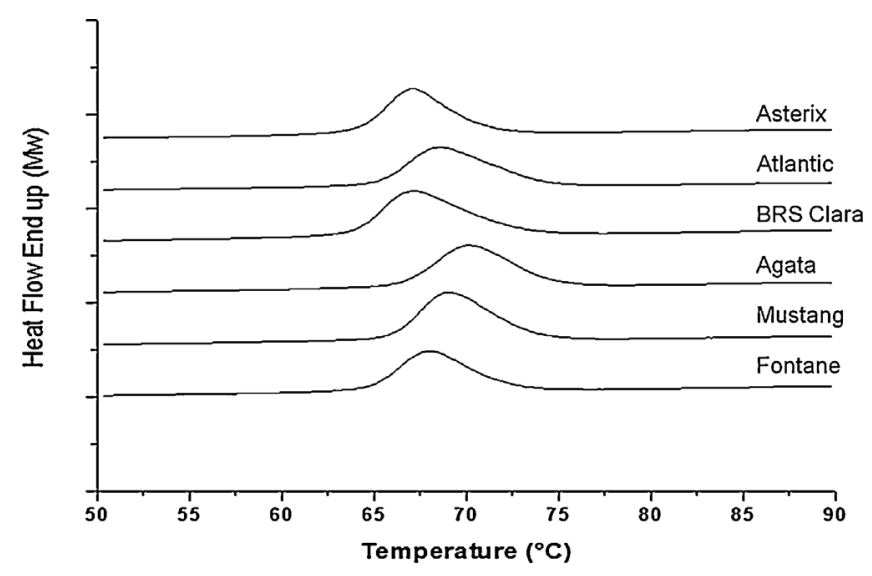

Fig. 2. DSC curves of investigated potato starches. obtained were similar to those presented by Kaur et al. [11] who evaluating some properties of potatoes starches found that the endothermic peaks for different potato cultivars ranged from 59.96 to $68.89^{\circ} \mathrm{C}$, the temperature of peak ranged from 63.37 to $64.58^{\circ} \mathrm{C}$, and the final temperature ranged from 67.4 to $68.9^{\circ} \mathrm{C}$. But the range of enthalpy of gelatinization observed by these authors was lower than obtained in this research.

Starch from cultivars Asterix and BRS Clara showed higher amylose content than other (Table 1), and Asterix showed lower onset and peak temperature and lower enthalpy change of gelatinization. This fact could be due to these starches have more short chain length and lesser crystalline regions. The cultivar Mustang showed different behavior, low amylose content and low enthalpy change of gelatinization, and high onset temperature. Amylose content is one of the main factors that affect the physicochemical properties of starch, and higher amylose content may lead to a higher gelatinization temperature, lower peak viscosity and breakdown [29].

When starch is heated in the presence of enough water its crystalline organization decomposes to form amorphous regions. This molecular disordering is called gelatinization. Differential scanning calorimetric (DSC) identifies melting and crystallization events as well as glass transition temperatures. DSC provides a simple method for measuring the heat energy required for starch gelatinization [30].

The extension of crystalline perfection is reflected at the gelatinization temperature range and the change of enthalpy obtained by DSC [31]. Starches from different potato cultivars showed small range of gelatinization temperature and also showed high variation 
Table 2

Thermal properties of gelatinization and retrogradation (DSC) of potato starches.

\begin{tabular}{|c|c|c|c|c|c|c|}
\hline \multicolumn{7}{|c|}{ Gelatinization properties } \\
\hline Samples & $T_{\text {onset }}\left({ }^{\circ} \mathrm{C}\right)$ & $T_{\text {peak }}\left({ }^{\circ} \mathrm{C}\right)$ & & $T_{\text {final }}\left({ }^{\circ} \mathrm{C}\right)$ & $\Delta T\left({ }^{\circ} \mathrm{C}\right)$ & $\Delta H\left(\mathrm{Jg}^{-1}\right)$ \\
\hline Asterix & $64.64 \pm 0.04^{\mathrm{a}}$ & $67.32 \pm 0.12^{\mathrm{a}}$ & & $71.13 \pm 0.11^{\mathrm{a}}$ & $6.49 \pm 0.05^{a}$ & $15.54 \pm 0.16^{\mathrm{a}}$ \\
\hline Atlantic & $65.57 \pm 0.08^{a}$ & $68.74 \pm 0.00^{c}$ & & $74.26 \pm 0.06^{\mathrm{bc}}$ & $8.94 \pm 0.44^{b}$ & $17.74 \pm 0.13^{\mathrm{b}}$ \\
\hline BRS Clara & $64.65 \pm 0.03^{a}$ & $67.74 \pm 0.00^{\mathrm{b}}$ & & $73.44 \pm 0.10^{\mathrm{bc}}$ & $8.70 \pm 0.17^{b}$ & $16.45 \pm 0.48^{\mathrm{ab}}$ \\
\hline Ágata & $66.66 \pm 0.40^{\mathrm{a}}$ & $70.17 \pm 0.35^{d}$ & & $74.80 \pm 0.05^{c}$ & $7.94 \pm 0.41^{\mathrm{ab}}$ & $17.80 \pm 0.50^{\mathrm{b}}$ \\
\hline Mustang & $66.29 \pm 0.18^{a}$ & $69.08 \pm 0.24^{c}$ & & $73.32 \pm 0.21^{\mathrm{b}}$ & $7.01 \pm 0.30^{\mathrm{a}}$ & $16.30 \pm 0.04^{\mathrm{a}}$ \\
\hline Fontane & $65.13 \pm 0.09^{a}$ & $68.16 \pm 0.11^{\mathrm{b}}$ & & $72.55 \pm 0.18^{\mathrm{ab}}$ & $7.43 \pm 0.28^{\mathrm{ab}}$ & $17.85 \pm 0.49^{\mathrm{b}}$ \\
\hline \multicolumn{7}{|c|}{ Retrogradation properties } \\
\hline Samples & $T_{\text {onset }}\left({ }^{\circ} \mathrm{C}\right)$ & $T_{\text {peak }}\left({ }^{\circ} \mathrm{C}\right)$ & $T_{\text {final }}\left({ }^{\circ} \mathrm{C}\right)$ & $\Delta T\left({ }^{\circ} \mathrm{C}\right)$ & $\Delta H\left(\mathrm{Jg}^{-1}\right)$ & $R(\%)$ \\
\hline Asterix & $42.46 \pm 0.45^{a}$ & $53.11 \pm 0.11^{\mathrm{a}}$ & $63.74 \pm 0.67^{a}$ & $21.28 \pm 1.12^{\mathrm{a}}$ & $5.34 \pm 0.04^{\mathrm{a}}$ & $35.44 \pm 2.04^{\mathrm{a}}$ \\
\hline Atlantic & $41.71 \pm 0.56^{\mathrm{a}}$ & $54.04 \pm 0.95^{\mathrm{a}}$ & $66.40 \pm 0.37^{\mathrm{abc}}$ & $24.70 \pm 0.93^{\mathrm{bc}}$ & $6.41 \pm 0.03^{b}$ & $36.22 \pm 0.23^{\mathrm{a}}$ \\
\hline BRS Clara & $41.55 \pm 0.59^{a}$ & $53.28 \pm 0.11^{\mathrm{a}}$ & $67.33 \pm 0.38^{\mathrm{bc}}$ & $25.78 \pm 0.98^{\mathrm{bc}}$ & $6.98 \pm 0.11^{\mathrm{c}}$ & $41.28 \pm 0.30^{\mathrm{bc}}$ \\
\hline Ágata & $42.89 \pm 0.66^{\mathrm{a}}$ & $54.62 \pm 0.12^{\mathrm{a}}$ & $66.00 \pm 0.73^{\mathrm{abc}}$ & $23.11 \pm 0.06^{\mathrm{ab}}$ & $6.39 \pm 0.10^{\mathrm{b}}$ & $35.38 \pm 0.17^{a}$ \\
\hline Mustang & $41.11 \pm 0.10^{\mathrm{a}}$ & $53.31 \pm 0.37^{a}$ & $68.37 \pm 0.01^{c}$ & $27.26 \pm 0.11^{\mathrm{c}}$ & $6.70 \pm 0.23^{c}$ & $42.66 \pm 0.94^{c}$ \\
\hline Fontane & $41.53 \pm 0.36^{a}$ & $53.45 \pm 0.59^{a}$ & $64.82 \pm 0.62^{\mathrm{ab}}$ & $23.30 \pm 0.98^{\mathrm{ab}}$ & $6.64 \pm 0.05^{c}$ & $37.21 \pm 1.31^{\mathrm{ab}}$ \\
\hline
\end{tabular}

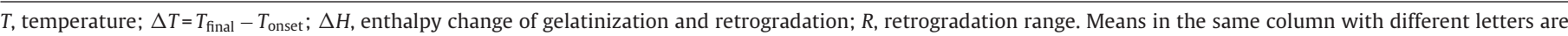
significantly different $(p<0.05)$.

Table 3

Pasting properties of investigated potato starches (Rapid Visco Analyzer).

\begin{tabular}{|c|c|c|c|c|c|}
\hline Sample & Peak viscosity (RVU) & Breakdown (RVU) & Final viscosity (RVU) & Setback (\%) & Pasting temp. $\left({ }^{\circ} \mathrm{C}\right)$ \\
\hline Asterix & $593.55 \pm 0.53^{a}$ & $258.31 \pm 2.00^{\mathrm{a}}$ & $396.97 \pm 2.77^{d}$ & $61.73 \pm 0.24^{c}$ & $70.98 \pm 0.04^{\mathrm{a}}$ \\
\hline Atlantic & $1004.14 \pm 22.09^{d}$ & $677.81 \pm 17.43^{d}$ & $367.31 \pm 0.06^{c}$ & $40.98 \pm 4.59^{\mathrm{a}}$ & $71.93 \pm 0.04^{\mathrm{a}}$ \\
\hline BRS Clara & $795.18 \pm 14.84^{c}$ & $502.13 \pm 17.20^{c}$ & $346.61 \pm 1.65^{\mathrm{b}}$ & $53.56 \pm 4.01^{\mathrm{bc}}$ & $71.08 \pm 0.11^{\mathrm{a}}$ \\
\hline Ágata & $645.28 \pm 8.54^{\mathrm{b}}$ & $310.92 \pm 11.49^{b}$ & $393.38 \pm 0.41^{d}$ & $59.02 \pm 3.36^{\mathrm{bc}}$ & $73.50 \pm 0.07^{b}$ \\
\hline Mustang & $812.76 \pm 4.48^{c}$ & $520.21 \pm 4.71^{\mathrm{c}}$ & $333.20 \pm 1.18^{a}$ & $40.65 \pm 1.41^{\mathrm{a}}$ & $71.80 \pm 0.07^{a}$ \\
\hline Fontane & $827.25 \pm 8.84^{c}$ & $530.37 \pm 8.25^{c}$ & $346.99 \pm 3.12^{b}$ & $50.10 \pm 2.53^{\mathrm{ab}}$ & $71.05 \pm 0.14^{\mathrm{a}}$ \\
\hline
\end{tabular}

RVU, rapid visco units; temp., temperature. Means in the same column with different letters are significantly different $(p<0.05)$.

of enthalpy change, suggesting a greater perfection and homogeneity of the crystals. On cooling, the disaggregated starch molecules first form a gel and then retrograde gradually into semi-crystalline aggregates that differ in form from native granules. The recrystallization, which occurs during long storage period, is attributed to amylopectin fractions [32].

The analysis of the thermal properties of retrograded starches showed reduction of the onset, peak and final temperatures when compared with those obtained for native starches (Table 2). This reduction occurs because of an improper alignment of the chains of amylopectin during the re-associating, causing formation less ordered and less stable crystal structures than those existing in the native starch. In this way less energy is required to melt the crystals [32,33].

The potato starches showed high values of retrogradation range (Table 2), which may suggest that these starches exhibit higher proportion of very long branched chains of the amylopectin. According to Rocha et al. [34], there is a relationship between higher proportions of branched chains of amylopectin with high rates of retrogradation.

The pasting characteristics play an important role in the selection of a variety for use in the industry as a thickener and binder. The pasting properties of potato starches are presented in Table 3. The peak viscosity, breakdown, final viscosity and setback of potato starches varied greatly, while similar pasting temperature were observed.

The Ágata cultivar present significant difference of pasting temperature for other, with highest value $\left(73.50^{\circ} \mathrm{C}\right)$, however, lower values were found by Liu et al. [35]. The starch of the cultivar Atlantic showed highest peak viscosity (1004.14 RVU), while starch of cultivar Asterix showed lowest peak viscosity (593.55 RVU). Asterix cultivar also showed lowest breakdown (258.31 RVU) while Atlantic had higher value (677.81 RVU). The inverse behavior was observed in setback, so the Asterix had the highest value while Atlantic had the lowest (Table 3). These results are according to correlation between higher amylose content and lower phosphorus content (Tables 1 and 4), which lead to lower peak viscosity and breakdown, but higher setback in potato starches, due to network of amylose content $[20,36]$.

Gelatinization occurs when native starch is heated in the presence of sufficient moisture. The granules absorb water and swell, and the crystalline organization is irreversibly disrupted. Amylose molecules begin to leach from the granules as they are disrupted under shear and the viscosity of the resulting paste increases to a maximum, which corresponds to the point when the number of swollen but still intact starch granules is at a maximum. The maximum is followed by a decrease in paste viscosity, as the granules rupture and starch molecules are dispersed in the aqueous phase [5].

The viscosity of breaking permits evaluating the stability of the product at high temperatures under mechanical stirring and is directly related to the peak of viscosity [37]. The peak height at a given concentration reflects the ability of the granules to swell freely prior to physical breakdown. Starches that are capable of swelling to a high degree are also less resistant to breakage during cooking showing significant decrease in viscosity after reaching the peak $[38,39]$. In the cultivars Asterix, Atlantic and Ágata was observed significant decrease in viscosity after reaching the peak, presenting values of breakdown almost half of the values of peak viscosity, showing that these starches are less resistant to cooking.

Pearson correlation coefficients amongst starch properties are shown in Table 4. Protein content was negatively correlated to the enthalpy change of gelatinization $(r=-0.65, p<0.01)$ and crystallinity index $(r=-0.56, p<0.05)$. Lipids content was positively correlated to the final temperature of gelatinization $(r=0.49$, $p<0.05)$ and retrogradation range $(r=0.67, p<0.01)$. Amylose 


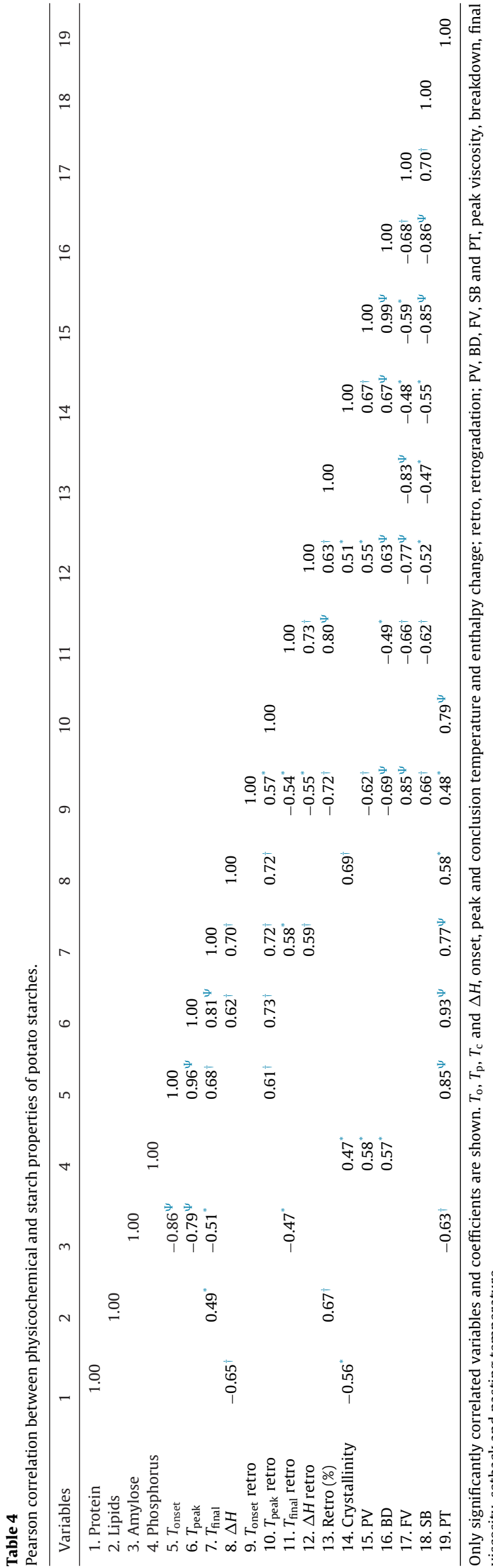

content was negatively correlated to the onset, peak and final temperature of gelatinization, final temperature of retrogradation and pasting temperature. It is widely accepted that high amylose is the major factor contributing to low peak viscosity, since the extent of starch swelling is presumed to be interrupted by an increase in the amylose content [29,40-42]. However, Wiesenborn et al. [22] and Ganga and Corke [43] reported that the amylose content did not have an effect on the peak viscosity for potato starch. In this study, there was no correlation between the viscosity peak and breakdown for the potato starch as also observed by Karim et al. [20] and Noda et al. [7].

Phosphorus content was positively correlated to crystallinity index $(r=0.47, p<0.05)$, peak viscosity $(r=0.58, p<0.05)$ and breakdown $(r=0.57, p<0.05)$ confirming that the phosphorus content affect pasting properties in potato starch [7,20,44]. Nutting [45] reported that when potato starch is pasted its phosphate groups ionize leaving the starch with a negative charge, resulting in the slight Coulombic repulsion that opens up the branched amylopectin molecules and increases their salvation. Compared with an electrically neutral starch this increased solvation results in larger pasted granules and a higher starch paste viscosity [45]. No correlation between setback and phosphorus content was observed in this study as also observed by Lu et al. [44]. However this correlation was observed by Noda et al. [7]. Analysis of phosphorus content is assumed to be useful for predicting the pasting properties in potato starch [7] and have directly correlates to the pasting properties of starch [44].

Generally, the thermal properties of starch studied by DSC are mainly based on the crystallinity of the amylopectin in starch granule. High phosphorus content is usually associated with a larger amount of amylopectin, rather than directly correlating to transition enthalpy of starch. However, the phosphorus content did not have an impact on this study, which agrees with previous reports [23,46-48].

Enthalpy of gelatinization ( $\Delta H_{\text {gel }}$ ) gives an overall measure of crystallinity (quality and quantity) and is an indicator of the loss of molecular order within the granule. The amount of doublehelical order in native starches should be strongly correlated to the amylopectin content and granule crystallinity increases with amylopectin content [49]. In this study, the enthalpy change was positively correlated with the crystallinity index $(r=0.69, p<0.01)$ and also correlated with pasting temperature $(r=0.058, p<0.05)$ and peak temperature of retrogradation $(r=0.72, p<0.01)$. Whereas the enthalpy change of retrogradation was positively correlated with retrogradation range $(r=0.63, p<0.01)$, crystallinity index $(r=0.51, p<0.05)$, peak viscosity $(r=0.55, p<0.05)$ and breakdown $(r=0.63, p<0.001)$, and negatively correlated with final viscosity $(r=-0.77, p<0.001)$ and setback $(r=-0.52, p<0.05)$. Generally, gelatinization temperature and enthalpy change are positively correlated to the stability crystalline structures [50], but this correlation was not observed in this study. Crystallinity index showed correlation with pasting properties, being positively correlated to peak viscosity and breakdown, and negatively correlated to final viscosity and setback.

\section{Conclusion}

The growing starch markets have led to food industries to a constant demand for starches with specific properties that meet the demands of applicability. In this way have increased the studies on native starches that can have characteristics of commercial interests. This study showed that starch extracted from important potato cultivars grown in Brazil differed in the physical, chemical and rheological properties. All samples showed a typical B-type Xray pattern. The phosphorus content of the starches had a more 
pronounced effect than the amylose in paste properties. Starches extracted from Asterix, Ágata and Atlantic cultivars showed low hot paste stability with stirring. Starches from different potato cultivars showed small range of gelatinization temperature and also showed high variation of enthalpy. The potato cultivars showed potential as a source of native starches in Brazil.

\section{References}

[1] FAO - Food and Agriculture Organization, Production Crop Data, 2014 Available from: http://faostat3.fao.org/browse/Q/QC/E.

[2] D. Gómez-Castillo, E. Cruz, A. Iguaz, C. Arroqui, P. Vírseda, Effects of essential oils on sprout suppression and quality of potato cultivars, Postharvest Biol. Technol. 82 (2013) 15-21.

[3] L.G. Padua, Cultivares de batata, in: L. Zambolim (Ed.), Produção integrada da batata, vol. 1, Suprema Gráfica e Editora Ltda, Viçosa, 2011, pp. 251-300.

[4] J. Jane, Current understanding on starch granule structure, J. Appl. Glycosci. 53 (2006) 205-213.

[5] L. Copeland, J. Blazek, H. Salman, M.C. Tang, Form and functionality of starch, Food Hydrocoll. 23 (2009) 1527-1534.

[6] A. Kaur, N. Singh, R. Ezekiel, H.S. Guraya, Physicochemical, thermal and pasting properties of starches separated from different potato cultivars grown at different locations, Food Chem. 101 (2007) 643-651.

[7] T. Noda, S. Tsuda, M. Mori, S. Takigawa, C. Matsuura-Endo, N. Hashimoto, H. Yamauchi, Properties of starches from potato varieties grown in Hokkaido, J. Appl. Glycosci. 51 (2004) 241-266.

[8] A. Viksø-Nielsen, A. Blennow, K. Jorgensen, K.H. Kristensen, A. Jensen, B.L. Moller, Structural, physicochemical, and pasting properties of starches from potato plants with repressed r1-gene, Biomacromolecules 2 (2001) 836-843.

[9] S. Hizukuri, S. Tabata, Z. Nikuni, Studies on starch phosphate: part 1. Estimation of glucose 6-phosphate residues in starch and the presence of tuber bound phosphate(s), Starch 22 (1970) 338-343.

[10] C.M.L. Franco, A.F.R. Cabral, D.O. Tavares, Structural and physicochemical characteristics of linnerized native and sour cassava starches, Starch 54 (2002) 469-475

[11] L. Kaur, N. Singh, N.S. Sodhi, Some properties of potatoes and their starches II. Morphological, thermal and rheological properties of starches, Food Chem. 79 (2002) 183-192

[12] F.H.G. Peroni, T.S. Rocha, C.M.L. Franco, Some structural and physicochemical characteristics of tuber and root starches, Food Sci. Technol. Int. 12 (2006) 505-513.

[13] AOAC - Association of Official Analytical Chemists, Official Methods of Analysis of the Association of Official Analytical Chemists, 18th ed., AOAC, Washington, DC, 2006.

[14] ISO - International Organization for Standardization, Norme Internationale: Riz-détermination de la teneur em amylose. S. l., 1987, 5 pp. ISO 66470.

[15] E. Malavolta, H.P. Haag, F.A.F. Mello, M.O.C. Brazil Sobrinho, Mineral Nutrition and Fertilization of Cultivated Plants, Pionera, Sao Paulo, 1974.

[16] S. Nara, T. Komiya, Studies on the relationship between water-saturated state and crystallinity by the diffraction method for moistened potato starch, Starch 35 (1983) 407-410.

[17] M. Leonel, S.B.S. Sarmento, C.M.L. Franco, M. Oliveira, M.P. Cereda, Avaliação de cultivares de batata-doce como matéria-prima para extração de amido, Braz. J. Food Technol. 7 (2004) 47-55.

[18] A. Buléon, P. Colonna, V. Planchot, S. Ball, Starch granules: structure and biosynthesis, Int. J. Biol. Macromol. 23 (1998) 85-112.

[19] T. Noda, S. Tsuda, M. Mori, S. Takigawa, C. Matsuura-Endo, S.-J. Kim, N. Hashimoto, H. Yamauchi, Effect of potato starch properties on instant noodle quality in wheat flour and potato starch blends, Starch 58 (2006) 18-24.

[20] A.A. Karim, L.C. Toon, V.P.L. Lee, W.Y. Ong, A. Fazilah, T. Noda, Effects of phosphorus contents on the gelatinization and retrogradation of potato starch, J. Food Sci. 72 (2007) 132-138.

[21] I.A. Veselovsky, Biochemical and anatomical properties of starch of different varieties of potato and their importance for industrial purposes, Am. Potato J 17 (1940) 330-339.

[22] D.P. Wiesenborn, P.H. Orr, H.H. Casper, B.K. Tacke, Relationship between potato starch paste behavior and selected physical/chemical properties, J. Food Sci. 58 (1994) 644-648.

[23] Y.S. Kim, D.P. Wiesenborn, P.H. Orr, L.A. Grant, Screening potato starch for novel properties using differential calorimetry, J. Food Sci. 60 (1995) 1060-1065.
[24] H.F. Zobel, X-ray analysis of starch granules, in: R.L. Whistler (Ed.), Methods in Carbohydrate Chemistry, vol. 4, Academic Press, New York, 1964, pp. 109-113.

[25] H.F. Zobel, Starch crystal transformation and their industrial importance, Starch 40 (1988) 1-5.

[26] J. Jane, Y.Y. Chen, L.F. Lee, A.E. McPherson, K.S. Wong, M. Radosavljevic, T. Kasemsuwan, Effects of amylopectin branch chain length and amylose content on the gelatinization and pasting properties of starch, Cereal Chem. 76 (1999) 629-637.

[27] V.A. Protserov, V.G. Karpov, G.O. Kozhevnikov, L.A. Wasserman, V.P. Yuryev, Changes of thermodynamic and structural properties of potato starches (Udacha and Acrosil varieties) during biosynthesis, Starch 52 (2000) 461-466.

[28] S. Hizukuri, T. Kaneko, Y. Takeda, Measurement of the chain length of amylopectin and its relevance to the origin of crystalline poly-morphism of starch granules, Biochim. Biophys. Acta 760 (1983) 188-191.

[29] K. Pycia, L. Juszczak, D. Galkowsk, Physicochemical properties of starches obtained from polish potato cultivars, Starch 64 (2) (2012) 105-114.

[30] Q. Liu, X. Lu, R. Yada, The effect of various potato cultivars at different times during growth on starch content determined by DSC, J. Therm. Anal. Calorim. 79 (2005) 13-18

[31] R.F. Tester, Properties of damaged starch granules: composition and swelling properties of maize, rice, pea and potato starch fractions in water at various temperatures, Food Hydrocoll. 11 (1997) 293-301.

[32] S. Srichuwong, T.C. Sunarti, T. Mishima, N. Isono, M. Hisamatsu, Starches from different botanical sources: contribution of amylopectin fine structure to thermal properties and enzyme digestibility, Carbohydr. Polym. 60 (2005) 529-538.

[33] A. Karim, M.H. Norziah, C.C. Seow, Methods for the study of starch retrogradation, Food Chem. 71 (2000) 9-34

[34] T.S. Rocha, I.M. Demiate, C.M.L. Franco, Structural and physicochemical characteristics of Peruvian carrot (Arracacia xanthorrhiza) starch, Food Sci. Technol. 28 (2008) 620-628.

[35] Q. Li, E. Weber, V. Currie, R. Yada, Physicochemical properties of starches during potato growth, Carbohydr. Polym. 51 (2003) 213-221.

[36] I.S.M. Zaidul, N.A.N. Norulaini, A.K.M. Omar, H. Yamauchi, T. Noda, Correlations of the composition, minerals, and RVA pasting properties of various potato starches, Starch 59 (2007) 269-276.

[37] M. Leonel, M.P. Cereda, Physicochemical characterization of some starchy tubers, Food Sci. Technol. 22 (2002) 65-69.

[38] N. Singh, J. Singh, L. Kaur, N.S. Sodhi, B.S. Gill, Morphological, thermal and rheological properties of starches from different botanical sources, Food Chem. 81 (2003) 219-231.

[39] N. Singh, N. Isoro, S. Srichuwang, T. Noda, K. Nishinan, Structural, thermal and viscoelastic properties of potato starches, Food Hydrocoll. 22 (2008) 979-988.

[40] L.S. Collado, R.C. Mabesa, H. Corke, Genetic variation in the physical properties and environmental factors, Starch 48 (1996) 167-171.

[41] C.K. Black, J.F. Panozzo, C.L. Wright, P.C. Lim, Survey of white salted noodle quality characteristics in wheat land-races, Cereal Chem. 77 (2000) 468-472.

[42] T. Beta, H. Corke, Noodle quality as related to sorghum starch properties, Cereal Chem. 78 (2001) 417-420.

[43] Z.N. Ganga, H. Corke, Physical properties of starch of Asian-adapted potato varieties, J. Sci. Food Agric. 79 (1999) 1642-1646.

[44] Z.-H. Lu, R.Y. Yada, O. Liu, B. Bizimungu, A. Murphy, D. De Koeyer, X.-O. Li, R.G. Pinhero, Correlation of physicochemical and nutritional properties of dry matter and starch in potatoes grown in different locations, Food Chem. 126 (2011) 1246-1253.

[45] G.C. Nutting, Effect of electrolytes on the viscosity of potato starch pastes, J. Colloid Sci. 7 (1952) 128-139.

[46] A. Blennow, A.M. Bay-Smidt, C.E. Olsen, B.L. Møller, The distribution of covalently bound phosphate in the starch granule in relation to starch crystallinity, Int. J. Biol. Macromol. 27 (2000) 211-218.

[47] T. Noda, S. Tsuda, M. Mori, S. Takigawa, C. Matsuura-Endo, K. Saito, M. Wickramasinghe, A. Hanaoka, Y. Suzuki, H. Yamauchi, The effect of harvest dates on the starch properties in various potato cultivars, Food Chem. 86 (2004) 119-125

[48] M. Yusuph, R.F. Tester, R. Ansell, C.E. Snape, Composition and properties of starches extracted from tubers of different potato varieties grown under the same environmental conditions, Food Chem. 82 (2003) 283-289.

[49] D. Cooke, M.J. Gidley, Loss of crystalline and molecular order during starch gelatinization: origin of the enthalpy transition, Carbohydr. Res. 227 (1992) 103-112.

[50] J. Singh, O.J. McCarthy, H. Singh, P.J. Moughan, Low temperature post-harvest storage of New Zealand Taewa (Maori potato): effects on starch physicochemical and functional characteristics, Food Chem. 106 (2008) 583-596. 